Título do Trabalho

\title{
A EMERGÊNCIA DA SOCIOLOGIA AMBIENTAL EXEMPLIFICADA NO MUNICÍPIO DE RIBEIRÃO PRETO SOB A ÓTICA DA QUESTÃO DO LIXO
}

Nome do Autor (a) Principal

Carolina Kotchetkoff Henriques

Nome (s) do Orientador (a) (s)

\section{Sérgio Azevedo Fonseca}

Instituição ou Empresa

Universidade Estadua Paulista - UNESP - Campus Araraquara

E-mail de contato

Krol_koff@hotmail.com

Palavras- chave

Sociologia Ambiental. Educação ambiental. Desenvolvimento

\section{INTRODUÇÃO}

Este trabalho propõe a reflexão sobre a importância da sociologia ambiental para auxiliar problemas socioambientais num momento em que se desenvolve uma sociedade caótica de produção, consumo e consequentemente lixo. A geração excessiva de lixo parece inevitável e consequência da falta de interesse em se preservar o meio ambiente, idéia que não é considerada lucrativa numa época em que a sociedade é comandada pelo 
capitalismo e pelo lucro. Esta disciplina se desenvolve num momento denominado de "modernidade tardia" e, portanto é recente e pouco difundida. No entanto ela possui um caráter plural, revelando que pode ser utilizada de diversas formas, tanto de um modo educativo como de uma maneira praxiológica, influenciando uma gestão socioambiental. Esta multidisciplinaridade é essencial para o estudo socioambiental pois é sua pluralidade que revela que quanto mais completo o estudo, mais eficaz ele se mostra. A sociologia ambiental consegue relacionar temas sociais, ambientais, econômicos, educativos, especificidades locais entre outros.

Sobre este ponto de vista, a educação se coloca como fundamental para direcionar um novo desenvolvimento local e diferenciado e para auxiliar numa conscientização mais eficiente ao ser inserida na sociedade desde a educação escolar até o poder público e privado.

\section{Objetivo geral}

Primeiramente busca-se definir e contextualizar o que seria a Sociologia Ambiental e em seguida anunciar sua importância como parte de uma educação ambiental para que seja uma ferramenta para um desenvolvimento consciente, revelando seu caráter educativo.

Ela se define como um novo "molde" da Sociologia clássica com uma posição mais crítica e profunda sobre a relação do homem com a natureza. A evolução do pensamento socioambiental cresceu na década de 60. O movimento ambientalista marcou uma contestação de valores que anunciava a modernidade tardia. Inicia-se ai uma conscientização permanente sobre a degradação ambiental com a industrialização. 


\section{Objetivos específicos}

O objetivo é testar empiricamente a praticidade da sociologia ambiental através através de um estudo de caso no município de Ribeirão Preto - SP, fornecendo formas de se pensar alternativas que contornem um problema socioambiental através desta disciplina.

O estudo aborda a gestão dos resíduos sólidos, suas dificuldades e a problemática do lixão municipal, de modo que se comprove que a falta de uma educação ambiental interfere no tipo de desenvolvimento local enquanto que uma sociologia ambiental pode infiltrar na educação, na gestão municipal e nos problemas de caráter social e ambiental de modo geral, auxiliando num novo padrão de desenvolvimento e sustentabilidade.

A temática do lixo foi escolhida por ser um bom exemplo de um problema multidisciplinar, como a disciplina em questão, pois engloba questões sociais, ambientais e econômicas, além de ter uma proximidade com a sociedade, que pode contribuir diretamente para amenizar o problema através da educação e da mudança de hábitos.

Em ribeirão há ainda outro problema, pois o lixão está localizado numa área de recarga do Aqüífero Guarani. Estes fatos já caracterizam a emergência de uma análise socioambiental local para buscar alternativas para o problema.

\section{Metodologia}

Este trabalho possui uma metodologia histórica e teórica para compreender a sociologia ambiental desde seus fundamentos e definições até os dias atuais. Além disso, realizou-se um estudo de caso sobre o município de Ribeirão Preto, através de materias 
bibliográficos encontrados na Secretaria do Meio Ambiente da cidade e de teses sobre o assunto.

\section{Resultado}

Ribeirão Preto é uma das cidades mais populosas do estado e seu padrão de vida elevado influencia no consumo e consequentemente na produção de lixo. A primeira Lei a respeito da coleta surge 40 anos depois do seu surgimento em 1856. Em 1917 o lixo era transformado em adubo para fazendas da região, mas deixou de ser utilizado quando o saco plástico substituiu o latão reduzindo assim a qualidade do lixo tornando-o menos biodegradável. Com isto surgiu o lixão, local de depósito do lixo sem nenhum tipo de tratamento que gera inúmeros problemas ambientais e socias (como por exemplo a questão dos catadores que tiram sua subsistência do lixo). A construção de um aterro sanitário, que é um local de tratamento dos resíduos, não resolveu os problemas e a coleta seletiva, que foi iniciada apenas na decada de 90, também falhou por conta de falta de fiscalização e uma má gestão.

Percebe-se que a situação dos resíduos é grave por conta da proximidade com o Aquífero Guarani e pela falta de ação para solucionar o problema, o que reduz a qualidade do desenvolvimento local. O gerenciamento adequado deveria levar em consideração as especificidades locais e uma categorização dos resíduos que inclui número de habitantes, atividade predominante, variações climáticos, costumes populacionais, poder aquisitivo, eficiência das leis e não menos importante o nível educacional da população. o estudo realizado mostrou que a coleta seletiva feita por bairro era desigual, e a quantidade e qualidade do material reciclável variava de acordo com a educação que a população teve sobre o assunto. Ou seja, a educação novamente é o fator essencial para a eficácia de um programa. 
O resultado é que a falta de uma educação ambiental interfere na qualidade da gestão municipal, que neste exemplo se mostra incapaz de solucionar os problemas presentes.

\section{Considerações finais}

Foram abordados dois temas: a sociologia ambiental e a problemática dos resíduos em Ribeirão Preto. A conclusão de que há um déficit na educação, como na gestão, abre uma porta para a sociologia ambiental. Esta deve ser empregada como instrumento de auxílio para superar esta situação, podendo elaborar alternativas viáveis ao desenvolvimento pela sua facilidade de ser inserida na sociedade como um todo, desde a escola até o poder público e privado. A proposta é notar que as duas temáticas podem se relacionar através da educação e a partir disto providenciar uma gestão eficiente. Não é difícil perceber que a educação ambiental inserida nas escolas facilitará uma conscientização das gerações futuras, e a disciplina, através de seu conceito de multidisciplinar, pode criar uma gestão municipal que agrega valores sociais, ambientais, econômicos com especificidades locais para que possa ser mais eficiente e duradoura. $\mathrm{O}$ município precisa conciliar todos os fatores relevantes para criar uma gestão eficiente. No caso dos resíduos, isto se dará quando os fatores ambientais de preservação, fatores sociais para solucionar a questão dos catadores, e fatores econômicos para viabilizar um programa, forem analisados por uma perspectiva educativa para que juntos consigam elaborar um projeto responsável e consciente.

\section{Referências}


BUTTEL, FREDERICH. A sociologia e o meio ambiente: um caminho tortuoso rumo à ecologia humana. Ed 1992. São Paulo, SP.Editora Perspectivas. 26 p.

CARDOSO, V.A. Gerenciamento do resíduo sólido domestico da cidade de Ribeirão Preto (SP): histórico, avaliação e recomendações. 2004. 175 f. Dissertação (mestrado em engenharia civil) - Faculdade de Engenharoa civil, Arquitetura e Urbanismo, UNICAMP, Campinas.

GIDDENS, ANTHONY; BECK, ULRICH; LASH, SCOTT. Modernização reflexiva. Ed. 1996. São Paulo, SP.Editora Unesp .268 p.

HALL, S. A identidade cultural na pós-modernidade. Ed.1997.Rio de Janeiro, RJ. DP\&A Editora. 102 p.

HANNIGAN, JOHN. Sociologia Ambiental. Ed. 2009. Petrópolis, RJ. Editora Vozes. $272 \mathrm{p}$.

LENZI, Cristiano Luis. Sociologia Ambiental: risco e sustentabilidade na modernidade. Ed. 2005. Bauru, São Paulo. Edusc Editora. 216 p.

REVISTA Política e Sociedade - Dossiê Sociologia Ambiental. Vol 4. N. 07 Universidade Federal de Santa Catarina. 2005. 213 p. 